\title{
Historein
}

Vol 14, No 2 (2014)

Historein 14/2 (2014)

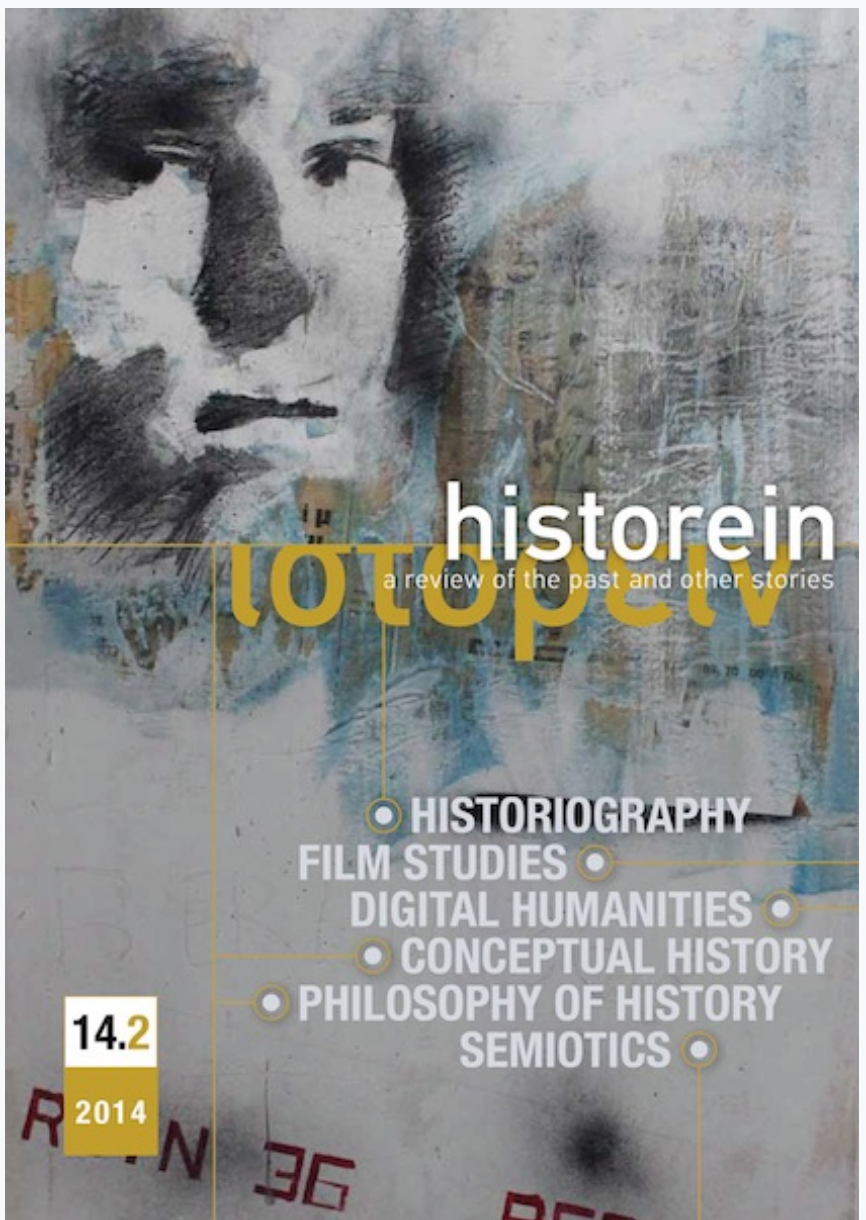

\section{Narrative engulfment: the public intellectual and narrative misrepresentation}

\section{Sande Cohen}

doi: $10.12681 /$ historein. 253

\section{Copyright () 2015, Sande Cohen}

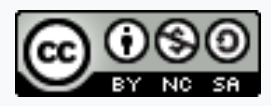

This work is licensed under a Creative Commons Attribution-NonCommercialShareAlike 4.0.

\section{To cite this article:}

Cohen, S. (2014). Narrative engulfment: the public intellectual and narrative misrepresentation. Historein, 14(2), 7-17. https://doi.org/10.12681/historein.253 
In Symbolic Economies, J.-J. Goux notes that intrinsic to a historicity of money, "once" the latter is made a general equivalent, is the process of "centristic tendencies"; today, this is called "too big to fail". This phrase is adequate to not just finance and labour, but also to art - the emergence of the global "biennale". Historicity is the ascent and triumph of subordinations around centrisms and their antagonisms, the money/ commodity schism incessantly linearised, driven by the downcoding of a Hegelian model, the "cunning of reason", into an encoding via what the great historiographer Karl Lowith called "the wasteful economy of history", or capitalism-live. History as engulfment. Fully developed capitalist regimes bring "limitless interrelation", what Deleuze and Guattari would call breakdowns. The continuous history of capital is super-storied as "matter conceived as void of sense", where "pure composition" magnetises and funnels subjective, monetary and symbolic values towards what today is called consumerism. 'The ultimate "matter" "void of sense" is, of course, that black hole called the subject who lacks, infinitive form. Lyotard called the psychologisation of capital the triumph of lack: we are not allowed not to lack. (Complementary, Roland Barthes argued that in myth, concepts distort sense and meaning, or myth produces another kind of lack.) In the face of these two rather overwhelming negatives, the organisation of life in such societies is regulated by a how-to-ism, a radical operationalism of "limitless interrelation". If "lack" goes with subjectivity, excess goes to the dominant: the destruction by the Clinton administration of the Glass-Steagall separation in 1998, which prevented banks from mixing deposits and investments, resulted in surplus leveraging, just as surely as China's underway relocation of 250 million farmers into cities is
Narrative

engulfment: the

public intellectual

and narrative

misrepresentation

\section{Sande Cohen}


carried out because they are deemed redundant (a blockage) to other profits-to-come. In this, historiography makes itself into an ingredient of both critique and rationalisation, in various mixtures. Narratives of change and transformation can just as easily generate misleading notions of continuity as they can of the force of discontinuity. The combinations are multiple: narratives of the avantgarde in America inflate the radicalism of art-as-discontinuity and narratives of capital deflate the discontinuities Americans "receive" from the economy. There are so many comparisons regularly churned out by school, government, think tank inter alia, that one can ask why we are not, say, flooded with narratives about the number of Americans actually employed, the lowest percentage in its "history", but such small narratives are shelved on the margins.

Historical narration requires a plunge - one narrates from vast amounts and intensities of information and data with their attending (or dominant) interpretations and returns, surfaces, with a procedure of present orientation - that may or may not be more than a further rationalisation of a particular subject. I am speaking of academic writing, i.e. narratives of globalisation that emphasise positive continuity and de-emphasise social discontinuity. In mass-writing, the New York Times has run continuous stories about the American civil war for a few years now, keeping its "presence" alive as a decisive continuity which sustains current political topics, i.e. racism in America. But critical historiography notices that the past returned to a now is a deeply political formation - making the now continuous with a present is already a command, even if softly couched in the discourse of drawing lessons. Promises "from history" are highly questionable. As will be discussed, to name the 2008 exposure of financial explosions/implosions a "crisis", from which were issued forth the polarity of austerity versus spending as narrative choices, is already containment and misleading. So let me start with the notion that critical historiography in a here and now has to ask how groupsin-conflict use history for control: Levi-Strauss' question, history for whom?

This essay is directed to a here and now, its subject the resuscitation of mainstream American liberalism's narrative of the Great Recession, almost universally "dated" from 2008 with the collapse of Lehman Brothers in New York. Great Recession is a vicarious substitution, hence already located by comparison with the Depression of 1929, but downcoded - less negative, less severe. Overnight, this dated event/process was immediately narrated as the avoidance of a Second Great Depression. It was, via astounding degrees of media attention (including scholarly ones), a historiographic catastrophe - the processes that generated the said "crisis" are still those of the dominant economy; massive reconstitutions of capital continue to flow into whatever and wherever they can; historiography was mostly not used to provoke criticism. In the critique which follows, this "now" has been put to rueful narrative functions; the primary one, that of narrative continuity, restored to and from this "crisis", in which avoidance-as-event created narratives that void, rather than open to, an extensive analysis of other processes. The period under consideration - 2008 to today - is read as wildly contentious processes and actions brought under control. What follows then is an analysis and discussion of narrative terror - the use of narrative to both softly (but relentlessly) frighten a population (here, readers of the New York Times, a population of spectators) and give rationalisations over the quantity of time necessary for putting into place techniques that have managed to control labour, money, and much more. The American political system, and not only that, has put in place devices and techniques, from law to invitations to a new subjectivity (i.e. reality television 
humiliations), to have made notions such as recovery and avoidance collective rationalisations, escapes, displacements, integrations, and, yes, still more. So the actual "subject" here is the politics of narrative. Narrative is always a political tactic: because stories are used to name, date, include, exclude, elevate and distort, leave in/leave out.

In societies riven by conflict, historical narratives rarely set forth the breaking of social rules and conditions, one version of this brilliantly sketched by Vico. In the course of events, he argued, "'obstinate factions' and 'desperate civil wars"' employ the "barbarism of reflection" or otherwise perpetuate conditions of relentless subjective irony transferred to every level/type of existence. ${ }^{2}$ In this, historical consciousness remains pinned to offering reflection that is no value at all. Or, worse: such narrative-driven consciousness offers reflection that continues barbarism, one "more barbarous than primitive savagery, inasmuch as it is unrestricted by the fear and ignorance" of earlier moments. ${ }^{3}$ One of the themes of this essay is the "barbarism of the smart", that is, the relentless success, across every mainstream institution, of the binary of austerity/spending, which operates as an anti-intellectual (critical) tool, hinged to a narrative of recovery that is systematically misleading. The modalities of historical consciousness may have bearings initiated in a present, but may return to render tomorrow in systematic modes of self-deception. Martin Davies has called this a condition of historicisation: narratives are rendered that make "present prehension [aesthesis]" controlled by "extensive abstraction", which brings with it redundancy, fundamentalism, and despondency. ${ }^{4}$ I do not think I have to stress that thousands of books and tens of thousands of journalistic articles have made current economic conditions representable, but overwhelmingly narrated in the name of existing powers, of all sorts. The "barbarism of reflection" Vico alluded to is just the transformation of information and knowledge into the force of management by those who already wield considerable control, including new ones. I first discuss some philosophical-critical notions of capital/ism, to ensure that the analysis of mainstream economic narratives is located in necessarily contestable set(s) of relations. Then I have some comments on what constitutes a "public intellectual", the one, the who, that changes public "opinion", makes a difference. And from there, I sail, with Kant's version of Captain Cook, into the somewhat twisted harbour of the New York Times and Paul Krugman.

Let's start with what should be obvious but commonly obscured: every concept in contemporary economics is, speaking in the idiom of food, half-baked - the plurality of discursive and institutional uses makes it impossible to present economics as conceptually intact. Every concept considered autonomously economic belongs at once to its significatory classes and kinds, or concepts that provide operations of identification and yet are often further de-territorialisations: the derivative market calls itself secondary (derivative as adjective and adverb), but it is also primary in actual practices. Economic concepts, definitions and the like are not free from the semiotically encoded vicarious substitutions and delegations of specific actions. Every conjunction between, say, moneyas-bill payment and power-as-capital testifies to this. In semiotic terms, the concepts discussed below are simultaneously over- and under-coded, contextualised and de-contextualising. To give powerful and stable names to things and relata is to impose order that is all the way through unstable. The arts and humanities, if one likes, live on such relations. So rather than start directly with analysis of the New York Times and its main economic writer, I should like to begin with a critical mode of historiographic perspective. 
First, taking into account new types of violence in the social system - here, for example, the collapse of Lehman Brothers in 2008, one can refer to arguments about the movement from production to reproduction. These are "loaded" terms, without doubt, but suggest, in line with arguments made by Baudrillard, that go to the dissolve of symbolic codes replaced by semiotic ones. This is capital conceived through a "structural law of value", as Baudrillard's Symbolic Exchange and Death (1976) put it, a hyper-reality of societies in which every action is subject to a "generalised manipulation". ${ }^{5}$ Capitalist practices micrologise, for instance, in the emergence of fees for small things or the transfer of services from providers to users. Notions of production, value, worth, equivalence, fairness, recovery, stasis and the like are made functionally mythical in regimes where sign-exchange value rules - labour reproduces itself in a repetition of commutable signs within an operational rather than a significatory field. A labour degree-zero? The famous current CEO salary that is 400 times the worker's income is based on codes of service, which has little to do with labour-time. ${ }^{6}$ Service means many things, one of them protection of the power to expand. As Baudrillard argued, the "fundamental mentality of capital" towards labour may well have been organised as investment/wages for workers, but now frantic activity and perpetual crisis (cf. Spain, Greece, Detroit) open not as indices to "criteria of equivalence" but rather to relentless speculation. ${ }^{7}$ Nothing, it seems, remains of any distinctive labour theory of value, despite important attempts to sustain it. ${ }^{8}$ It would also seem that every philosophy of history which talks about outcomes, goals, ends, aims, means and the like is condemned to notions of growth or "production for production's sake" that involves the reinvestment of interest (surplus); money truly has no equivalent as it "plays" out in "transfers and writings, according to an incessant splitting and increase of its own abstract substance." ${ }^{\text {" }}$ What does money measure? Eric Alliez, writing in Capital Times, has a completely different time-point for capital - already in ancient Greece, money became a device of "appropriating expropriation" or where the "aberration movement" (synthesised in Benjamin Franklin's "money is time") allowed "money [to be] torn from its political condition of mediating need to become the number of an artificial and convulsive movement". ${ }^{\circ}$ It was interest, according to Alliez, that brings with it "the homogeneration of time, the register of an abstract, infinitely divisible time". "Surplus value of code into a surplus value of flux," wrote Deleuze and Guattari in Anti-Oedipus, so that money was split into payment for consumption (wages) and money used to speculate - "a prospective force or ... long-term evaluation, not realisable hic et nunc."11 Formations of money, for example exchange money and credit money, do not have a "common measure", so that temporal relations reproduce ceaseless displacements between money and commodity. ${ }^{12}$

No less problematic than money and economic concepts is the mystery of intellectual critique. In discussing, below, Krugman's texts and their location in the New York Times, it is impossible not to ask about public life. Can a critical narrative of these texts do more than indicate their intellectual value or their political positioning? In an essay, "The Public as Phantom", Bruce Robbins notes that evocations of a competent, informed, collective or mass "public" has always been a phantasmagoria in America, "an attempt to haunt us with the Spirit of the Past, an authoritative survival before which we should bow down in fear, awe, and silence". ${ }^{13}$ For Robbins, a left as such cannot do without invocations of a "public" even if the latter only exists as phantom. The vitality of the phantoms, it can be said, are now circulated mostly in academic and art domains, itself a confirmation of intensively riven vicarious relations, of every type and kind. In these places, there is still what 
Robbins calls a demand for politicisation that might be critical, but there is plenty of confusion by invoking a "public" without analysis of its "actual goals and values"; progressivism has tended to replace critique with expression, with inclusion of "other identities". A close reading of Krugman's use of narrative should illumine such topics.

Like the vast majority of Americans, I was a spectator at the media presentation of the financial turmoil that became explicit in 2008, turmoil fed by and saturated by various mediations. Enough discourse came from every direction to generate competitions over difficulties of representation, especially issues of the narrative incorporation of actual processes (i.e. an imploding stock market). The tribulations of a shrinking American middle-class came forward, including much incomprehension of contemporary economic practices. Multiple wars over narration did not, of course, predominate so as to generate systematic upheaval in relation to "public" life - five years later, there is no public discourse that stands opposed to the fix-it-up and patch-it-up actions of economic activity and narrative presentation. Important and initial mediatised representations of financial mayhem came during the Obama and McCain debates. At one point, they were asked what defined middle-class, heading straight for the territory of class trouble. Without missing a beat, they agreed that an income of $\$ 250,000$ per year was the upper-threshold of middle-class. I watched this debate in Phichit, Thailand, with Thai teachers - who were stunned, since they knew that the median household income of Americans is $\$ 50,000$; what kind of political-numerical magic had taken hold in America? How could Americans listen to such narrative appropriations of descriptive fictions? Be that as it may, from the moment "too big to fail" was issued forth as the state response, issues of dependency, debt, consumption and much more were recalibrated; narratively, the freezing of credit was instantly a scare story: what if people could not borrow? That, in turn, belongs to a possibly more disturbing narrative of debt - the "fuel" which makes for a future (tomorrow), since today one's subjective present (presence) involves so much future speculation. In the sense of Arthur Danto's Analytical Philosophy of History, "too big to fail" is a temporal structure - the phrase serves as criteria by which different social agents and actors, including institutions, can pick and choose narrative sentences by means of which significance is assigned to events at earlier and later moments. Which certainly means other processes and events can be disregarded. As Danto put it, 'words like 'fatal', 'destined', 'doom', dramatise what is an essential fact about the historical organisation of the past". "Too big to fail" also served as a narrative ethos - stories of debt, success, impasse, failure, recovery and the like were given sense - stories of woe and advantage, fairness and injustice, and much more, easily fit with the dramatics of "too big to fail". Thus, "too big" immediately led to narratives of "recovery" insofar as a kind of solvency was promised, one of the oldest and well-worn illusions of collective identity. From a critical perspective, 2008 was worded-up as an immense spectacle of patching.

The stories told, most drawn from pre-existing narratives, turned actualities into discourse, into wordedness. With exceptions, the strange locution that a "2nd Great Depression" had been avoided by state action took hold, with the media and highly visible commentators telling us the federal government "knew" it had only a few days to provide a backstop after the collapse of Lehman Brothers. Apart from a few commentators who argued for no state intervention - widely associated with letting banks and other institutions dissolve, a call for narrative rupture, and located by mainstream mediators as libertarian (or worse) - there was a quickly dominant narrative rush, an exceeding- 
ly political action that turned narration into a weapon. With historicisation one of the stakes, or the processing of the contemporary into narrated duration, the effective capture of wildly different experiences and interpretations also dominated. The narrative of avoidance "won"; what did not happen (2nd Depression) thus "happened". The success of an absence is a strange cultural-intellectual phenomenon. As with every narrative, criteria have to be offered so as to select actions, processes and projects which are, again in Danto's terms, "changes ... nested within changes, and stories [that] require increasingly complex middles to explain the outermost change". He illustrated this as: $(()(())())$, which visually alludes to multiple causation, overdetermination, and narrative overlap.14 "Avoided" was differently placed - at once a terminus, a result and a beginning, but also a possible "middle" of other stories (i.e. a pause in financial chaos) as well as a "beginning" of an ending not written. Unfortunately, Danto also stressed that "social inheritance" frequently allows one to use concepts "built up over the generations" so that we explain "avoidance" and "too big to fail" through "immediacy and certitude." The certainty of "too big" joined to "avoidance" seems to have encoded satisfaction from "avoidance", a narrative generating a pause in social contention. "Too big to fail" and "avoidance" were not thought of and acted on as "unprecedented" and cannot be explained, I think, except by the observation that acceptance of the concept of "avoidance" was also a suppression of aspects of social reality deemed too intractable to deal with. Danto thought we have no option but to explain change via conventions that "like events have like causes" or "constant conjunctions". 15 While it seems incontestable that Danto's affirmation of Humean causal analysis is widely accepted, it seems to me that if narrative sentences assign significance to some events and processes and consigns others to a sort of oblivion, "like" and "constant" are precisely ideological forms. To even call 2008 a financial "crisis" built around the concept of "too big to fail" is to bring to 2008 a vast discursive arrangement - the entire historiography of financial-social disturbance, surprise, the unexpected, where the "normal" (what is held to be "normal") has actually upended itself, while it was also used to set off a restoration of the "normal. "Like" and "constant" are meta tags of an identitarian order.

Here, one can note that "too big to fail" has been from the start shadowed by "recovery", that somewhat creepy sense of redragged into actions of return and repetition of the normal. From the perspective of what Danto called temporal placement, the fusion of "too big to fail" and "recovery" or past-referring descriptions that are also future-evoking statements, swamped present-tensed conflict: instead of "avoidance of a 2nd Great Depression" evaluated as a, say, Lyotardian differend, where events are made to go into discourses that cannot be mastered or that open to what discourse releases as incommensurable, one receives redundancy. As a Lyotardian differend, "too big to fail" and "avoidance", open to an abyss, on the one hand the vast ignorance of capital in the US and the equally vast conformities of acceptance of that ignorance. From any metahistorical perspective, there is something peculiar that belongs to the dominant narratives. What present economic reality is about, including processes not readily available to the "general population", did not receive much narrative treatment; what happened was the installation of a continuous narrative in which "avoidance" was the escape hatch for what is now an endless stream of stories, many encoded as beautiful data in those university generated charts and graphs which give a ceaseless visual supply of misleading comparisons.

A kind of collective sensibility was achieved, that the present is one of continuous time relations, even though many groups immediately felt the discontinuous, or future-differences. The suture 
of past and present was accomplished through a dominant media and institutional reiteration of a narrative with a large number of substories, images, concepts, and a lot more. What did not happen - a 2nd Depression - became the informing content and substance. The internet amplified the "real" of this and produced its own distortions, especially, as said, a vast number of charts and graphs showing just about every possible combination of depth and scale: 1929 to 2008 , endless comparisons, a kind of horror of comparison, each one relentless in its "facticity" or claim to accuracy, to disclose a piece of the real. Insofar as any comparison is an opportunity for ideological self-confirmation, as well as for a serious misrepresentation, intellectual collateral damage from the "too big" inter alia has been severe.

And the discourses were unequal: the statements of a Federal Reserve chief were hardly on the same level as statements made by millions of ordinary citizens who, in jokes, worries, editorials, everyday conversations and the like, circulated "too big to fail" in a phased movement (narrative) from a bureaucratic discourse that refers to operational efficacy to senses and images of both popular satisfaction and malaise. Time magazine featured Bernanke as a "hero" of capital, where the notion of avoidance was joined to a real oxymoron, the positive failure of another Great Depression. In sum, "too big to fail" coils more than one narrative or story, not least the sense that the "heads" of society are relatively untouchable, as it also involves a sense of mass-fatalism - an impossibility of difference. The phrase evoked some scepticism, but without force - as I write this (May 2013), the financial system as a whole does pretty much what it wants, including a recent amendment to congressional financial regulations (Dodd-Frank) directly written into law by Citibank attorneys. It is worth saying here that while notions of process and discourse are entirely contestable, it is a fact on the ground that assigning common causality and responsibility was immediately made irrelevant unless there was (is) undeniable law-breaking; devoid of a legal process having massively intervened, financiers such as George Soros still say such things like "Financial crises are not caused by speculators, but by the authorities, which create or establish the wrong rules that allow speculators to do what people blame them for. In other words, to put it more clearly, speculators are messengers delivering bad news." ${ }^{16}$ That's an astoundingly self-serving rhetorical blowtorch - how can Soros get away with saying such things? Because his discourse is "too big to fail"? Legal discourse, including how laws have been written to protect the "too big to fail", did not capture the narrative of "too big to fail" - the narrative of that is another story, of escape from responsibility by means of "the law".

Unequal discourse - Soros' statements widely circulated, given impact and repetition in their sheer irresponsibility or displacement of responsibility, that concept suffocated by social position and the abuse of the law, joins with the narrative of the avoidance and then failure of Great Depression 2 - and overlaps with financial dominations that have a life of their own. In sum, "too big to fail" was institutionalised in bailouts inter alia, one of its senses given privilege over others. The phrase was differently activated - a marker of technocratic "speak", a jargon, but one with a large reach.

Now, asking, with Robbins' comments about a/the public and phantoms, Krugman's stories and op-eds in the New York Times opinion pages offer no shortage of large and small narratives of inequality, poverty, job loss, restructuring of the American economy inter alia, particularly as they stay away from issues of income, gouging and outright financial manipulation - unless heavily 
dramatised, as with the Bernie Madoff "case". Overall, Krugman's op-ed columns and blog force continuity between the Democratic Party and its progressive wing, which amounts to a defence of "cheap" money and Keynesian spending in periods of slump and recession. He has devoted many columns to the obvious truism of stupidity among some Republicans, most of which read as cherry picking; a relentless focus on the distribution of wealth to the 0.1 or 1 percent of wealth holders displaces any analysis of the wage surplus in the US, that is, for example that student loans in the University of California system first pay California bond interest, or that academia as such is now 70-75 percent part-time labour vis. an increasingly remote tenure group; the model of New York high-life is the mark of the civilised who have "earned" their privilege, including the "good academic" who practices enlightened social science, in general promoting the reproductive procedures of Democratic candidates in public life. In sum, a kind of Clintonism, with university and financial overlap - a process in which institutions, academics, policies, writing laws, enacting regulations or otherwise setting up tactics and strategies that retain control not of the $1 \%$ übers, but of the next 11-15 percent below, that \$250,000 “middle-class" figure shared by McCain and Obama in 2008.

Here is Krugman's narrative version of the story (myth, fiction, model, concept) of "too big to fail":

The story, at this point, is fairly straightforward. The financial crisis led, through several channels, to a sharp fall in private spending: residential investment plunged as the housing bubble burst; consumers began saving more as the illusory wealth created by the bubble vanished, while their mortgage debt remained. And this fall in private spending led, inevitably, to a global recession. For an economy is not like a household. A family can decide to spend less and try to earn more. But in the economy as a whole, spending and earning go together: my spending is your income; your spending is my income. If everyone tries to slash spending at the same time, incomes will fall - and unemployment will soar. ${ }^{17}$

Notice that the link between "crisis" and "illusory wealth" is utterly cancelled by the stress on "economy as a whole", a fiction of the synecdochic kind - that there is a "whole" rather than a more disquieting narrative to which "all" cannot apply. And notice as well that the equation which makes for recovery is the identity of not-spending - so that now it is spending that is "too big to fail". That Krugman's use of history-as-narration infantilises is not, I think, contestable. Disturbingly, the editorials offer a bridge between academic culture and daily life of ordinary people in which critical analysis tends to be buried in academic journal literature, some of which at least tends to pose problems and not solutions..$^{18}$ For Krugman, over and again, narrative recovery, or recovering the narrative of fulfilment, takes up 2008 and after: 2008 created "inadequate demand" or consumption as narrative thwarted. On the subject of many years of asset price inflation, including homes and college tuitions, combined with wage stagnation for the majority of workers, Krugman sends forth narrative mystification, the refusal to explain. Thus, acknowledging that "finance economists rarely asked the seemingly obvious (though not easily answered) question of whether asset prices made sense given real-world fundamentals like earnings. Instead they asked only whether asset prices made sense given other asset prices," Krugman puts speculators, investors, or just about everyone, including academic economists implicated in this "great inequality", in the same bin: "The belief in efficient financial markets blinded many if not most." Explanation by blindness of course affirms a kind of infirmity to society, or "blinded" comes to mean the "system" is "too big to see"? 19 
Since 2008, Krugman and the New York Times have especially repelled a critique on the moralisation of the financial nastiness - lessening the chances for a critical analysis between the legal and the ethical. "Too big to fail" has been radically demoralised in favour of narratives that sustain the very processes of which "too big" is both cause and effect; the chief narrative being that consumer society requires liquidity provided by the very powers that cannot fail. It isn't any more sophisticated, as a semiotic notion, not a technical one, than a Bangkok taxi driver saying "no money, no honey". In this, the New York Times has tried to stabilise economic discourse and provide support for certain processes over others. In a general sense, all of the primary editorial writers in the Times radically deflate the negative or recode it. For example, mass suicides by Foxconn workers in China in 2010 did not deter Friedman from continuing to extol China as a "marvel"; David Brooks regularly cites "social scientific" research in psychology so as to affirm the "essential" soundness of the American Dream; Frank Rich ran a story on the death of diplomat Richard Holbrooke, neglecting to mention that Holbrooke's behaviour in East Timor (1975-80) abetted the Indonesian slaughter there; Stanley Fish spreads irony as if his readers shared irony as life's only existential condition. So I don't think there is a question that the main editorial writers at the New York Times favour a historiography that maintains, in general, what Bourdieu called the "liberal professions" protected by "legitimate distance, established by academic verdicts ... by meritocratic indignation" so as to privilege a certain kind of narrative, that progress incorporates and overcomes destruction of all kinds. ${ }^{20}$ In other words, progressive narrative hews to a teleology instead of a critique, which gives it the sense of an illusionistic general history. The visitations of increased structural poverty to many social groups is decried but, at the same time, the only politics allowed are those of the two parties whose very modes of reproduction have generated the contemporary wasteland of politics. ${ }^{21}$

Krugman attributes the financial crisis to "debt that households ran up" rather than the massive leveraging by institutions like Lehman, which at one point before collapse had debts 33 times its assets. Because recovery is a narrative process, the ongoing requirement is for the state to contest "deflation, not inflation, [which] is the clear and present danger". From the outset, Krugman has given no systematic analysis of the run-up in housing prices that continued from the mid-1970s to the present; even in deflated markets like Riverside, California; or Arizona or Florida, prices were markedly higher than average wages over this period. So why is deflation the problem? To say deflation is the number one targeted enemy of progressive economics, the narration informs itself - past inflations are not to be contested; it is quite paranoid that there should be no going back on previous inflations. This precludes analysis of what even basic statistics indicates, that the movement of income to the "top" is real and a mask for the more diffuse economy of services, which involves the professional classes in gouging, in exploitation. In actuality, conflict within the middle class is ruled out. In editorial after editorial, it is a given that "governments should be spending while the private sector won't, so that debtors can pay down debts without perpetuating a global slump". What matters, again, is narrative joined to rhetoric: the call for "debt relief" is only to ensure that debt continues - to prevent that nihilistic outcome, aka bankruptcies. To make debt payable locks in debt just as prior inflations are locked in. A critical narrative of inflation and "bubbles" ruled out, Krugman avoids the systematic, or simply the differential of the social, i.e. the switch from guaranteed pensions from the 1960s to 80 s and their replacement by volatile $401 \mathrm{~s}$. The stories reiterated in the New York Times instead emphasise a "deflationary trap", less spending and less borrowing, 
hence less employment, a narrative of labour treated in its most Dantoesque dramatic form: the frightfulness of unemployment. Fear is the architecture of narrative when it comes to unemployment - but only in a swerve from the more difficult analysis, if not genealogy of cost/price/profit/surplus, the complex of monetary forms of terror. ${ }^{22}$ In this, Krugman's relentless invocation of Keynesian spending versus the austerity model has come to serve for the progressive wing of the Democratic Party as their sole economic touchstone. It is surely highly political that Krugman's rhetoric emphasises separating country and family vis-à-vis what is the necessity of paying off debt for the latter and spending for the former, while insisting "my and your" spending is transferable, conceptually and practically, into the other. The schism of money and commodity discussed at the beginning is here confirmed by Krugman's rather schizophrenic rhetoric. Is Lawrence Summers' half-a-million fee for sitting on corporate boards really an effect of my income as spent? "My and your" is insisted as signifying an "our", as in common economy. But is there such a thing?

Synthesised many times since 2008 , here is a last and particularly striking version, drawing on economic history directly, a continuous antecedent, in which labour is as severely controlled as it is extolled. First, "if the real problem is that we overspent and lived beyond our means, we should be working harder, not throwing millions of people into unemployment". This bit of a return of the past, of its inflations not deniable, it is still employment which is the touchstone - it is presumed that any wage is better than nothing. This is yet another encoding of social terror - an intensification of labour, its devaluation. Second, a relentless defence of federal spending or taking on debt is required, and history is directly called upon: "In fact, when people used to refer to austerity Britain, they were referring to the half-dozen years after the war when Britain had very high public debt... There were exchange controls. There was financial repression. All very terrible things, unacceptable by modern standards, right? But there was full employment!" Thus, a positive past, a basis of comparison: "and everyone worked hard - but, you know, everyone had a job. We've responded to much lower levels of debt by ensuring that the economy functions far below potential, millions of people who want to work can't find jobs, and many people see all their hopes for the future slipping away."23 The stunning reduction - "everybody had a job" - is here turned into a narrative condition for a rejection of austerity as well as into a condition of existence of American society - neatly wrapped, enfolded and encoded, in terror. And one notes this is a safe opposition for mainstream liberalism - the opposition between "rentier" and the "unemployed", in which liberalism cannot lose. The "excessive" (the 0.1 to 10.0 of economic class fractions) versus the nearly apocalyptically encoded unemployable: "catering almost exclusively to the interests of rentiers - those who derive lots of income from assets, who lent large sums of money in the past, often unwisely, but are now being protected from loss at everyone else's expense". What is narrated is the loss of spendability, falling out of consumption, falling out. This is close to what Lyotard, previously referred to, considered the performance of lack, nonconsumption. Alternatives are presumably senseless. So rather than cogent analysis of how "too big to fail" came to be, Krugman targets: the Republican Party is the narrative home of the $0.1-1.0$ percent, the rentiers, and the rest of the society is relieved from any narrative in which self-implication might be discussed. ${ }^{24}$

Thus, "too big" and related notions are not only a condition of existence, a process and an event but also an event of historical narration - the stories told by Krugman, redundant in the extreme which deliver the product of the irrelevance of history to social understanding. 


\section{NOTES}

1 Jean-Joseph Goux, Symbolic Economies (New York: Cornell University Press, 1990), 44, 98,120. Karl Lowith, Meaning in History (Chicago: University of Chicago Press, 1949).

2 Hayden White, "The Tropics of History: The Deep Structure of the New Science," in Giambattista Vico's Science of Humanity, ed. Georgio Tagliacozzo and Donald Phillip Verene (Baltimore: Johns Hopkins University Press, 1976), 82.

3 White, "Tropics," 67.

$4 \quad$ Martin Davies, Imprisoned by History (London: Routledge, 2010), 35.

5 Jean Baudrillard, Symbolic Exchange and Death (New York: Sage, 1976), 3.

6 Baudrillard, Symbolic, 11, 17.

7 Baudrillard, Symbolic, 21.

8 See, especially, Gayatri Spivak, The Spivak Reader (New York: Routledge, 1996), 111.

9 Baudrillard, Symbolic, 21.

10 Eric Alliez, Capital Times (Minneapolis: University of Minnesota Press, 1996), xvii.

11 Gilles Deleuze and Felix Guattari, Anti-Oedipus (Minneapolis: University of Minnesota Press, 1983), 228.

12 Deleuze and Guattari, Anti-Oedipus, 231.

13 Bruce Robbins, "Introduction: The Public as Phantom," in The Phantom Public Sphere (Minneapolis: University of Minnesota Press, 1993), ix.

14 Arthur Danto, Analytic Philosophy of History (Cambridge: Cambridge University Press, 1965), 241.

15 Danto, Analytic, 242, 244.

16 "The Resistible Fall of Europe: An Interview with George Soros," Project Syndicate, accessed 16 Sept 2014. www.project-syndicate.org/commentary/the-resistible-fall-of-europe--an-interview-with-george-soros

17 Paul Krugman, “The Big Fail," New York Times, 6 Jan 2013.

18 Davies, Imprisoned, 28ff.

19 Paul Krugman, "How Did Economists Get It So Wrong," New York Times, 2 Sept 2009.

20 Pierre Bourdieu, Distinction, 303.

21 Jean-François Lyotard, Political Writings (Minneapolis: University of Minnesota Press, 1993), 67.

22 Paul Krugman, "The End of the Tunnel," New York Times, 8 October 2010.

23 Paul Krugman, “Old Fashioned Austerity," New York Times, 18 May 2013.

24 Paul Krugman, "Rule by Rentiers," New York Times, 10 June 2011. 